\title{
FUNCTIONAL PARADIGM OF SEMANTIC AND STYLISTIC INVERSION IN THE ORIGINAL AND TRANSLATED TEXT OF J. BARNES NOVEL "A HISTORY OF THE WORLD IN 10 ํㅡㄹ CHAPTERS"
}

Summary. Topicality of the problem raised in this article is determined by insufficient representation of J. Barnes' creative phenomenon, in particular his prose translation studies analysis, in the Ukrainian philological science. Complex nature of the postmodern belles-lettres discourse elucidation has been conditioned by its intertextuality and genre heterogeneity of its text parts. Non-linear narration together with the intricate combination of discourse samples belonging to various genres and styles in the text framework. Thus, the realistic illusion is made by means of its consideration from the psycholinguistic point. The latter concerns conceptual opposition emphasis as well the separate units stressing. An illusion is also made of the discourse parts reference to different psycho-emotional dominants; the latter generates the text versatility interpretations. In the analyzed work of fiction inversion (in combination with other stylistic means) performs semantic (plot-forming) and stylistic (expressive and pragmatic) functions. Inverted word order with an emphatic do is used for the subject elements emphasis; the negative inverted statements intend to intensify certain semantic components stressing in micro- and macrocontextual structure; inverted sentences with an introductory there were applied to emphasize and describe the depicted world picture components as the personages' psycho-emotional state indicators. The final analyzed sample provides a vivid example of the above. The emotive colouring has been achieved by actualizing expressive means belonging to different language levels; especially frequent is the use rhetoric questions and statements. The key feature of the translated text has been focused on rendering the functional and stylistic parameters of the source text into the target language. The compensatory means applied in the target text comprise inherent and adherent expressive elements of different language levels, punctuating marks intending to convey the belles-lettres text melodic sounding, and lexical units belonging to various registers.

Keywords: inversion, intertexuality, irony, postmodern prose, semantic and stylistic function, source text, translation.

Толочко О.Я.

Львівський національний університет імені Івана Франка

\section{ФУНКЦІОНАЛЬНА ПАРАДИГМА СЕМАНТИЧНОЇ ТА СТИЛІСТИЧНОЇ ІНВЕРСІЇ В ОРИГІНАЛЬНОМУ ТА ПЕРЕКЛАДНОМУ ТЕКСТІ РОМАНУ Д. БАРНСА «ІСТОРІЯ СВІТУ В 10 ํㅗㄹ РОЗДІЛАХ}

Анотація. Актуальність порушеної у статті проблеми полягає у недостатньому представленні творчого френомену Д. Барнса, зокрема перекладознавчого аналізу його прози в українській фрілологічній науці. Складність дослідження постмодерного дискурсу зумовлена його інтертекстуальністю та жанровою неоднорідністю різних частин тексту. Нелінійність наративу, складне поєднання різножанрових та різностильових елементів у канві тексту, а також створення реалістичної ілюзії, через його розгляд у психолінгвістичній перспективі. Це стосуеться наголошення концептуальних опозицій та окремих елементів, творячи ілюзію тексту іншої жанрово-стилістичної парадигми, а також аналізуючи контексти як картини світу з різною емоційно-смисловою домінантою, таким чином породжуючи багатогранність інтерпретації. В аналізованому творі інверсія (у поєднанні з іншими стилістичними засобами) виконує семантичну (сюжетотворчу) та стилістичну (експресивно-прагматичну) фрункції. Зокрема, інверсивну модель з допоміжним дієсловом dо в емфатичній функції вжито для наголошення суб'єктних елементів; заперечні інверсивні речення - посилюють протиставлення окремих компонентів смислової структури; речення з ввідним there використано для наголошення та опису складових зображеної картини світу як індикаторів психоемоційного стану персонажів. Особливо яскраво це демонструе останній наведений уривок тексту. Для творення емотивного колориту також актуалізовано засоби виразності, що належать до різних мовних рівнів; зокрема частим е використання риторичних запитань і тверджень. У тексті перекладу основним завданням стало передання цільовою мовою фрункціонально-стильової структури оригіналу. Інверсивний порядок слів у цільовому тексті збережено не у всіх випадках, ураховуючи значно менший його стилістичний потенціал в українській мові. Засобами компенсації емотивності у перекладному тексті слугують інгерентно та адгерентно експресивні одиниці різних мовних рівнів, знаки пунктуації (для увиразнення ритмомелодики дискурсу), а також використанні лексичних елементів, що належать до різних мовних регістрів.

Ключові слова: інверсія, інтертекстуальність, іронія, постмодерна проза, семантична та стилістична фрункція, оригінал, переклад.

Problem setting. Julian Barnes' novel "A History of the World in $101 \frac{1}{2}$ Chapters" is one of his most well-known works of literature among those firstly (if not the first one) translated into Ukrainian. Thus, the elucidation of stylistic categories (inversion in particular) in the original postmodern text structure and in the writer's individual style, together with the specificity of 
rendering the stylistic and aesthetic connotation of the inverted models into the target language. Thus, the mentioned issues present evident topicality in the contemporary philological science domain.

Theoretical background. Postmodernism as an integral multidimensional dynamic trend in literature and art is largely predetermined by social conditions [25, c. 24]. J. Barnes, however, states that his literary creative work can't be viewed as stable or solid, on the contrary, it must be perceived as the process constantly changing and evolving [2, c. 2]. The distinguishing feature of J. Barnes' narration in the analyzed text is its non-linear character aimed at failure to construct an objective picture of the past events, but in interpreting the way of such an illusion creation making parody a key stylistic means of the contemporary novel [8, c. 10]. Presenting history in all the diversity of its interpretations refutes the idea of its linearity and successive development of its events. Thus, the history perception and interpretation can't be confined to a single version. A separate variant or a story may be viewed as linear, while their multitude causes a chaos [8, c. 17]. J. Barnes' novel comprises text elements belonging to various genres and styles. Such a combination, however, contributes to the wholesome perception of literary work and interpretation its aesthetic value as shaped by means of reference to the writer's another text or works in the correlated discourse types, or works belonging to the authors of previous epochs [23, c. 38].

The texts containing such an information fulfill three basic functions: message conveyance, new sense generation, cultural memory codification [9, c. 15]. Ermines M. Novikova considers intertextuality as national and timeless in its manifestations. Thus, the artistic translation is regarded as languages, cultures, and mentalities dialogue as well as the dialogue of "the new and other" within the culture, and history is perceived as "the dialogue of epochs" [11, c. 147]. V. Kukharenko defines the belles-lettres text as an arranged system including three paradigms: genre, functional and stylistic, individual (writer's) system. The latter comprises works of the same writer, thus, revealing his creative strategy. The writer's strategy is disclosed in literary work genre specificity through the textual marker. The text genre largely determines its lingual framework, pragmatic features and the recipient response [10].

The objectives of this article lie in the elucidation of the semantic and stylistic parameters of the inverted syntactic models aimed at the emphasis of semantically and conceptually significant units bearing an apparent connotation displayed on the micro- and macrocontextual level as well on the whole text system with an account for its literary and genre specific features predominantly focusing on rendering the mentioned original text parameters into the target language.

The set objectives envisage an application of a number of methods, in particular the contextual analysis concentrated on studying the belles-lettres text as to functioning and interrelation of its units within the discourse framework; the distributional analysis focusing on a lingual unit posi- tion in relation to its environment. The elements of conceptual analysis (together with the componential and dictionary definitions analysis) are directed to disclosing an inverted element semantic structure. The stylistic text analysis deals with its linguistic research aiming to outline style parameters of the literary text stating, though, that the revealed features may be minor in the writer's creative strategy, at the same time, focusing on adequate comprehension of content and stylistic traits by the recipient readers [19; 22]. I. Galperin singles out following stages of the artistic text interpretation: (1) consideration of the text by its functional stylistic and genre parameters; (2) comprehensive analysis of the lexemes semantics in collocations they form on micro- and macrocontextual level: (3) an analysis of stylistic means in contrast to the neutral lingual elements; (4) the statement neutral elements role estimation, as well the generalization of attitude towards the depicted events characters [3]. V. Sdobnikov, a translation studies scholar, substantiated the fact that a word performing its aesthetic function constitutes an important tool of the artistic image formation; almost every word intends to reveal its stylistic potential in shaping a certain verbal image, even stylistically neutral lexemes are inclined to enter association ties [14]. Linguists prove an opinion that text interpretation constitutes a more complex phenomenon than its ordinary explanation. The grounds for the text perception lie in the subjective personal experience, and thus, entail the personal spiritual world psycholinguistic reconstruction [13, c. 41]. S. Zasyekin adheres to the conception that psycholinguistic view on adequacy of the artistic translation suggests that rendering the original content by means of the target language, i.e. the semantic structure and connotation framework, lies in the problem of the original and translated texts functions approximation, as their identity is impossible. The translation studies view on that issue provides for the consideration of translations as the acts of mental and speech behavior, with an account of such objective factors as creativity, strategy, translator's intuition [7]. B. Norman suggests that grammatical categories and ties both present the concentrated cognitive experience of previous generations and enable language representatives to systematically arrange the new information in statements relating to a certain syntactic model [12]. The statement's order (the so-called positional scheme) is defined as an invariant of plausible variation of the syntactic designation of a sole event, defining syntaxeme as a phrase or sentence element which, depending upon its position, performs a certain syntactic, and correspondingly communicative function within a statement framework [16]. Macrocontextual factor supplements semantic and stylistic functions of the contexts containing inverted sentences.

\section{Basic text.}

Let us consider the English belles-lettres contexts with inverted sentences and their Ukrainian equivalents, analyzing the ways of their semantic, stylistic and imagery loading conveyance in the target text: Noah and his wife had dark hair and brown eyes; so did Ham and his wife; so, for that matter, did Sham and Veradi and one whose 
name beginning with J had dark hair and brown eyes. And so did Cush, and Mizraim, and Canaan. But, Phut, one born on Ark, had red hair and green eyes. Red hair and green eyes. These are facts [30, p. 23]. Anthropocentric nature of cognitive human interaction with environment as well with the inner reflexive experience of another human being confirms universal character of the "one's own" and "extraneous" opposition. The latter constitutes psychological foundation of the acciological contrast of one's own as positive, secure, and well-known versus extraneous as negative, dangerous, strange [15, c. 196-211]. The detailed description of the Noah's family members' appearance has been realized in the inverted sentences where the mentioned elements nominating Noah's sons constitute subject-rhemes stressed with the help of emphatic do intensified by an adverbial element so. Together with the first statement the mentioned elements of the construction make up an abstract informational hypertheme contrasting with its hyperrheme expressed by the following sentence But, Phut, one born on Ark, had red hair and green eyes complemented by the nominative clause Red hair and green eyes and the final assertive statement These are facts enhancing the opposition. The Ukrainian translation Ной $i$ його дружина мали телне волосся й карі очі, так сало й Хал з дружиною; ну й так сало Сил, Вераді, й отой на букву "Я». I Куш був такий, й Мічрайл, і Ханаан. А от Фут, який народився на Ковчезі, був рудий. Рудий і зеленоокий. Такили $\epsilon$ фбакти. [29, с. 30-31] is different by its structure. The inverted word order in the statements of existential semantics has been used twice. The original inverted sentences with emphatic do have been transformed into repeated elliptical clauses connected copulatively and asyndatically, together with a simple sentence constitute the so-called context hypertheme. The following subordinate clause with a specifying attributive element, and the nominative adjectival phrase comprise heperrheme of the given abstract. The inverted simple sentence Такими е дракти is adherently expressive as if making a conclusion to the mentioned above.

The conceptual dichotomy of 'GOOD' versus 'EVIL' ("perfect" versus ugly") has been implicitly realized in the following abstract: What their status in the mighty hierarchy shall be - whether they be partly natural, whether they be living corruption, or whether they be creations of devil - is a matter of those great doctors of the Church who weigh such matters. Neither can we know all the myriad reasons why God should have permitted a plague of woodworm to infest this humble church [30, c. 78]. The first sentence makes a presupposition as one explaining and complementing the following inverted statement forming an empathy of the given statement. This syntactic makes a construction of suppositional modality consisting a number of rhetoric statements united by coordinated means asyndetically using a dash to indicate elliptical action character as well the unexpectedness of text transition [20, c. 501]. The usage of modal verbs in particular shall in the statement structure attaches a certain subjective connotation [8, c. 90-92]. Constituting empathy focus of the following inverted sentence designating God as the Absolute and woodworm as the devil creation, thus verbalizing the concepts 'SACRED' and 'UGLY' (vile). The first one is related to the divine existing beyond human world (paradise) as contrasted to imperfect mundane human world, as well associating it with hell [18, c. 872]. The Ukrainian equivalent Яке місие їй годиться приписати - чи то вона частково природна, чи живе в грісі, чи творіння диявольське - про ие судити лише великил Отиял Церкви. Тако же ved не можело ми знати легіон тих причин, з яких Бог міг би попустити нашестя черви деревної на Свій скролний храл [29, с. 90-91]. The target text structure in general adequately conveys the communicative and stylistic features of the original. As in the English discourse, the first sentence of the translated text discloses sense of the following statement. This syntactic coordinate structure forms a construction with its two parts separated by means of a dash. The first part consists of a number of rhetoric statements in the form of implicit interrogations. Its second part bears the key information and communication loading. The inverted word order has been preserved in its main part; the subordinate clause (correspondingly to the original) complements it expressing suppositional modality. The stylistically marked elements still intensify the abstract expressive colouring: i.e. equivalents of the metaphorized expressions plague of woodworm, creations of devil, living corruption; trite metaphorical phrases weigh such matters, myriad of reasons; adherently expressive word combinations Doctors of the Church, mighty hierarchy, humble churchнашестя черви деревной, творіння диявольське, живе в грісі; про ие судитилуть, легіон тих причин; великі Отиі Церкви, Свій скролний xpas, attaching a certain ironic connotation to the narration.

The irony of illusion in the text allusion to trial speech can be seen in the following context: If you summoned a rat before you, would you expect it to proceed to your court while passing through a town full of cats? And on this point, not only is the distance from the abode of bestioles to the court a monstrous league for them to travel, it is also one which they would accomplish under mortal threat of those predators which attend on their humble lives [30, p. 66]. The first sentence in its essence makes rhetoric question, though the following statement containing inverted construction with an emphasis of the noun distance ("an amount of space between two places or things") [28, p. 428]. Its semantic significance is revealed by the following discourse parts. The narration official character was achieved by the use of certain literary (bookish) lexemes in the metaphorized phrases the abode of bestioles, monstrous league for them to travel, under mortal threat of those predators from those predators, attend on their humble lives; and adherently expressive formalized phrases to proceed to your court, pass through a town, verbs summon(ed) referring to a noun rat, and travel acquiring sarcastic connotation in the given context [28]. The target equivalent $Y u$ покликавши на суд щура, ви б чекали, що він дійде до вас через все місто, повне котів? Тако 
же й відстань від обителі деревної черви до суду $е$, за ї̈ міркали велетенською, до того ж, сповненою слертельних небезпек від хижаків, що чигають на ї̈ скролні життя [29, с. 78], being structurally different from the original text presents a fairly adequate rendering of the source discourse expressiveness by attaching formalized ironic rhetoric to the translated variant. The negative inverted statement not only is the distance from the abode of bestioles to the court a monstrous league for them to travel is rendered in translation by means of declarative inverted sentence of existential semantics with its certain elements transformed, though with a successful suitable preservation of the original emotive colouring. The target lexical level as well contributes to attaching the relevant expressive tone: in particular, the metaphorized phrase monstrous league is rendered by the stylistically marked word combination велетенська (відстань) in the hyperbolized statement accomplish under mortal threat of those predators with its elements belonging to the principal part was translated literally - сповненою слертельних небезпек від хижаків with an attributive subordinate clause which attend on their humble lives, also not devoid of sarcastic shade was rendered into Ukrainian as що чигають на ї̈ скролні життя, containing an adherently expressive verb чигають (чигати) - «перебувати у певнолу місиі, очікувати кого-, чого-небудь» [27, т. 11, с. 321]. The translator made an interesting choice to still enhance the target discourse expressiveness by the use of conjunctive phrase тако же as in certain contexts conjunctions may bring an additional emotive shade [20]. In the analyzed abstract this element is aimed at attaching an "archaic tone" to the narration to evoke the relevant response from the recipient.

An artistic text constitutes the reality interpretation where the reflected picture of world serves a means of the writer's world picture restructuring, rearrangement and verbalization. Such a world picture has been endowed with specific parameters as well the emotional and notional leitmotiv forming a criterion for the belles-lettres texts typological classification [1, c. 72]. The scholar developed texts typology by their emotional and notional dominant criterion defining them as dark, light, sad, merry, active. The mentioned discourse types, however, may coexist within one work of fiction framework [1]. The following provided model may illustrate a pattern of the so-called dark sad text with a depressive and anaphoric shade: There are twenty figures on board. Two are actively waving, one actively pointing, two vigorously supplicating, plus one offering muscular support to the hailing figure on the barrel six in favour of hope and rescue. Then there were five figures (two prone three supine) two look either dead or dying, plus one old greybeard with his back to the sighted Argus in a posture of mourning: six against. In between (we measure space as well as mood) there are eight more figures: one-half-supplicating, three watching the hailer with non-committal expressions; one watching the hailer agonizingly; two in profile examining the waves past and the waves to come; plus one obscure figure in the darkest and most damaged part of canvas with head I hands (and clawing scalp?) Six, six and eight: no overall majority [30, c. 131]. The provided abstract gives a derailed description of the ship wreck. In J. Barnes' novel the ship (Noah's Ark) constitutes the so-called conceptual metaphor which is defined as "reality conceptualization method" by means of certain sphere entities interpretations in terms of the notions belonging to a different experience domain [26, c. 74]. The concept 'ARK' forms a dominant bibleme ("biblical intertext unit" manifested semiotically and cognitively verbalized archetypes, concepts, and symbols), or stylistically expressed on the stylistic micro-levels and in the text framework as its thematic and compositional component. The dominant bibleme determines and transforms the key intertext components [4, c. 205]. The detailed description of people situated on board was done by using inverted constructions with an introductory there for the subject syntactic elements emphasis specifying the personages' psycho-emotional state when being in danger, hoping for rescue and begging for it. The very emotion of fear reflects the human attitude towards oneself and the surrounding world. It is characterized by the changes in human behavior, and in combination with other feelings finds its reflection in language forms [8, c. 182-197]. The manifestation of fear may be accompanied by grief ("an extreme sadness", something that makes you feel extremely sad") [28, c. 671], as well causing affliction "something that causes pain or suffering" [28, c. 26] and dismay ("worry, disappointment or unhappiness you feel when something unpleasant happens") [28, c. 424; 5, c. 197-201]. In the provided context these two emotional states are caused by uncertainty, insecurity because of helplessness. The personages' emotional tension has been verbalized by means of their appearance, postures and actions description. The participle supplicating ("asking for help from someone in power or from God") [28, p. 1553] belongs to the bookish vocabulary, it intensifies the text expressiveness and complements semantics of the lexeme supporting combined with an adverb half. The persons' looks are predominantly focused on the ship in hope for the rescue. Some of their actions designated still attach a more vivid colouring to the whole context - actively waving, actively pointing, vigorously supplicating, offering muscular support to the hailing figure on the barrel; these people postures and state - prone, supine, look either dead or dying, in a posture of mourning, with heads in hands, and clawing at (his) scalp still enhance a more remarkable emotive traits to the discourse framework. The Ukrainian equivalent Ha борту двадиять gбігур, двоє активно простягають руки в благальнолу жесті, один шосили підтрилуе того, хто махає, стоячи на бочщі: шість на користь порятунку $i$ надї. Відтак бачило п'ять gбігур (двоє долілиць, троє горілиць), які чи то мертві, чи то влирають, також одного сивого чоловіка, який сидить спиною до поліченого "Аргуса" в скорботній позі: шість проти. Посередині (i за просторол, $i$ за настроєм) бачило ше вісіл ббігур: один наполовину благае, наполовину підтримуе, троє без особливого виразу дивляться на того, хто махає кораблю, один - болісно, 
двоє у профбіль відповідно дивляться на хвилі, які насувають $i$ які вже пройшли, плюс одна ббігура в найтемнішій, найдужче пошкодженій частині полотна, яка зронила голову на руки (i рве на собі волосся?). Wiсть, шість, вісіл чіткої більшості нелає [29, с. 145-146] is generally focused on rendering the communicative and stylistic features of the original text. The target text, however, conspicuously differs as it consists of simple and elliptical sentences detached by a coma to accentuate the elements; semi colon and colon convey the breadth of sounding separating large in size syntactic structures while a dash is aimed to produce an action abruptness effect, and the unexpectedness of narration development. The notes in brackets intend to make specifications in the text framework [20]. Combination of the mentioned lingual elements shape the discourse emotive structure originality, the text lexical level components form the original text semantic structure giving detailed description of the personages', concentrating primarily on their emotional state through body posture, gestures and actions, thus attaching a shade of hypochondria, constituting a pattern of dark text. The final interrogative rhetoric phrase of the source text and clawing scalp was reproduced by an interrogative contextual equivalent $i$ рве на собі волосся "making a certain conclusion", at the same bringing uncertainty.

V. Belyanin, a psycholinguist finds ground for "the light texts in depicting the personal world as well the natural surrounding natural environment. Thus, the human being (personality) becomes an object of the vital activity [1]. The following sample provides an illustration: I had a good time in my wire cart. I remember when I used to go shopping, in the old days, the previous days, I'd sometimes see small kids, sitting inside a trolley as if it were a cage and being pushed around by their parents; and I'd be envious. I wasn't any more. And boy, did I buy some stuff that morning! [30, c. 327] The final sentence is endowed with a remarkable stylistic accentuation forming the structural and connotational realia in the English text with a lexeme boy functioning as an emotive word and constituting an emphasis focus (climax) of the provided abstract. The proceeding two sentences contain the s-called presupposition leading up to that point disclosing the causes of elation as one of the light texts key features. The given abstract lays a stress on the concepts 'TIME' as forming the predominantly abstract and relevant notion. This relevance finds its manifestation in ethnic languages and historical perspective. Such a perspective may acquire regressive linearity [17, c. 228-248], thus also verbalizing the concept 'REMINISCENCE' as "a memory (recollection) of the past events about somebody or something [24, c. 575]. The recalled childhood events became a source of pleasure, positive emotions causing a certain euphoria. The target text Мені подобається кататися на візку. Пал'ятаю, як сітчастолу візку, наче у клітиі, везли батьки; я тоді їл заздрив. Тепер перестав. Ух, чого я того ранку накупив! [29, c. 321] in general satisfactorily renders the semantic structure and expressive colouring of the source text making an exclamatory construction, thus preserving its functional and communica- tive accents by the reflection of its suppositional and climax elements. Correspondingly to the original text, in translation the crucial emotional emphasis was laid on final sentence, though the inverted word order had not been preserved; the target statement, however, conveys a certain rhetoric connotation. The English emotive word boy was rendered by means of interjection $y x$ is used to express an intense felling, exaltation [27, т. 10 , с. 525$]$ fairly adequately preserves pragmatic connotation of the original text.

Conclusions. Complex character of the postmodern literary discourse elucidation has been determined by intertextual and genre intricacy of its components. It is conditioned by postmodernism as the literature and art trend specificity, as well by J. Barnes - its bright representative creative method. This writer's prose is generally (and the analyzed novel in particular) characterized by the non-linear narration structure, as well by the intricate combination of text parts belonging to different genres and styles creating realistic illusion and parody considering the text in psycholinguistic perspective. The latter is aimed to designate concepts opposition or emphasize certain elements aimed at creating an illusion of a discourse part constituting a text sample of the different genre and style; as well the contexts representing various pictures of the world with different sense and emotional dominance forming grounds of the literary work multiple interpretations. Among the numerous stylistic means applied by the writer, inversion performs semantic (plot-developing) and stylistic (expressive and pragmatic) functions. The inverted models with an emphatic do to stress the subject elements; the inverted structures containing negation intensify contrasting of semantic and conceptual units; the inverted constructions with an introductory there intend to provide description of the artistic world picture components, as well specify the psycho-emotional state of the depicted personages by actualizing certain elements in the relevant concepts' framework. The identical task was attached to inversion in the last provided abstract indicating the person's elated mood and spiritual aspiration by referring to the past experience and reminiscences. To create the suitable emotive colouring the writer resorted to different language levels expressive means, in particular, frequent use of rhetoric questions and statements. To achieve adequate of the original text into the target language, the key task of the translator lied in preservation of the source text syntactic constructions' functional and communicative structure in the target discourse; in many cases, however, the original inverted word order was not used in translation due to the remarkably lower inversion expressive potential in the Ukrainian language. The compensatory emotive means used in target discourse include different language levels inherent and adherent expressive means as well punctuation means, and the lexical units belonging to various lingual registers.

The elucidation of J. Barnes' prose poetics remains insufficiently represented in the Ukrainian philolological science domain, thus, posing a topical trend for further research. 


\section{References:}

1. Belyanin, V. (1996). Vvedeniye v psikhiatricheskoye literaturovedeniye [Intriduction to Psychiatric Literature Studies]. München: VERLG OTTO SAGNER.

2. Bogdan, V. (2015). Julian Barnes. In Sovremennaya zarubezhnaya literature [Contemporary Foreign Literature], (pp. 9-24). Moscow: Flinta Nauka.

3. Galperin, I. (1976). O printsipakh semanticheskogo analiza stilisticheski markirovannykh otrezkov teksta [Of Semantic Analysis of the Stylistically Marked Text Abstracts]. In Printsypy i Metody Semanticheskikh Issledovaniy. Moscow: Nauka.

4. Dzera, O. (2017). Bibliyna intertekstual'nist' $i$ pereklad: anglo-ukrainskiy kontekst [Biblical Intetrtextuality and Translation: English-Ukrainian Context]. Lviv: Lviv National Ivan Franko University.

5. Dimitrova, E. (2007). Toska [Grief]. In Antologiya kontseptov V. Karasik, I. Sternin Ed. Moscow: Gnosis.

6. Zasiekin, S. (2012). Psykholingvistychni Universalii Perekladu Khudozhnyoho Textu [Psycholinguistic Universals in the Translation of Literary Text]. Lutsk: Volyn National University.

7. Zaykina, S. (2007). [Fear] In Antologiya kontseptov V. Karasik, I. Sternin Ed. Moscow: Gnosis.

8. Kolodinskaya, E.V. (2004). Istoricheskoye proshloye kak predmet vyskazyvaniya: sovremwnnaya angloeazychnaya istoriographiya (G. Swift, J. Barnes). [Historical Past as State Subject: Contemporary Anglophone Historiography G. Swift, J. Barnes]. Phd thesis review. 10.01.13 - "Foreign Countries Literature (European and American Literature)". Moscow.

9. Kuz'mina, N. (2006). Intertekst $i$ ego rol'v protsessakh evolliutsyi poetichskogo teksta [Intertext and Its Role in Poetic Text Evolution Processes]. $3^{\text {rd }}$ Ed. Moscow: KomKniga.

10. Kukharenko, V. (2004). Interpretatsiya tekstu [Interpretation of Text]. Vinnytsya: Nova Knyha.

11. Novikova, M. (2005). Mify i misiya [Myths and Mission]. Kyiv: DUKH I LITERA.

12. Norman, B. (2013). Kognitivnyi sintaksis russkogo yazyka [Cognitive Syntax of Russian language]. Moscow: Flinta.

13. Saprygina, N.V. (2012). Psikholingvistika khudozhestyvennogo teksta [Author and Reader Communication]. Odessa: Astroprint.

14. Sdobnikov, V. (2007). Teoriya perevoda [Theory of Translation]. Moscow: AST Vostok - Zapad.

15. Selivanova, O. (2012). Opozytsiya SVIY / CHUZHYI v etnosvidomosti (na materiali ukrains'kykh pareniy [ONE'S OWN / EXTRANEOUS Opposition in Ethnic Consciousness s Based on Ukrainian (Ethnic) Steriotypes]. In: Svit Svidomosti v Movi, O. Selivanova, (Ed.). Cherkasy: Yu. Chabanenko.

16. Selivanova, O. (2008). Suchasna lingvistyka: napriamy ta perspektyvy [Contemporary Linguistics: Trends and Prospects]. Poltava: Dovkillia-K.

17. Stepanov, Yu. (2004). Konstanty: Slovar' russkoy kul'tury [Constants: Russian Culture Glossary]. Moscow: Akademicheskiy proekt.

18. Silistika agliyskogo yazyka (1991) [English Stylistics]. O. Morokhovskiy Ed. Kyiv: Vyshcha Shkola.

19. Sukhorolska, S., \& Fedorenko, O. (2006). Methods of Linguistic Research. Lviv: Lviv Ivan Franko National University Publishing Center.

20. Suchasna Ukrains'ka Literaturna Mova. Stylistyka (1972) [Modern Ukrainian Literary Language. Stylistics]. I. Bilodid. (Ed.). Kyiv: Naukova Dumka.

21. Baker, M. (2006). In Other Words: A textbook of translation. L.\& N.Y.: Routledge.

22. Leech G., Short M. Style in Fiction A Linguistic Introduction to English Fictional Prose. Second edition. London \& New York: Longman, Pearson, 2007. 404 p.

23. Bolotnova, N. (2009). Kommunikativnaya stilistika teksta: slovar'-tezaurus [Communicative Stylistics of text]. Moscow: Flinta; Nauka.

24. Zhaivoronok, V. (2007). Znaky ukrains'koi etnokul'tury [Ukrainian Ethnic Culture Signs]. Kyiv: Dovira.

25. Literaturoznavchyi slovnyk-dovidnyk [Literature Studies Glossary]. R. Hromyak, Yu. Kovaliv, V. Teremko Ed. Kyiv: VTS "Akademiya".

26. Martynyuk, A. (2011). Slovnyk osnovnykh terminiv kohnityvno-dyskursyvnoi lingvistyky [Basic Cognitive and Discourse Linguistics Terms Glossary]. Kharkiv: RhNU imeni V. N. Karazin.

27. SUM (1970-1980). Slovnyk Ukrains'koi Movy. Kyiv: Academy of Sciences of Ukraine.

28. LED (2006). Longman Exams Dictionary. Edinburg: Pearson Education Ltd.

29. Barnes D. (2019). Istoriya svitu v $10^{1 / 2}$ rozdilakh [A History of the World in $10^{1 / 2}$ Chapters]. transl. by H. Yanovs'ka. Kharkiv: Knyzhkovyi Klub "Klub simeynoho dozvillia".

30. Barnes, J. (2009). A History of the World in 10 1/2 Chapters. London: Vintage.

\section{Список літератури:}

1. Белянин В.П. Введение в психиатрическое литературоведение. München : VERLG OTTO SAGNER, 1996. 281 c.

2. Богдан В.В. Джулиан Барнс // Современная зарубежная проза : Учеб пособие. Москва : Флинта Наука, 2015. C. 9-24.

3. Гальперин И.Р. О принципах семантического анализа стилистически маркированных отрезков текста. Приниипы и летоды селантических исследований. Москва : Наука, 1976. С. 284-289.

4. Дзера О.В. Біблійна інтертекстуальність і переклад: англо-український контекст : монографія. Львів : ЛНУ імені Івана Франка, 2017. 490 с.

5. Димитрова Е.В. Тоска // Антология концептов / под ред. В.И. Карасика, И.А. Стернина. Москва : Гнозис, 2007. C. $197-201$.

6. Зайкина С.В. Страх Тоска // Антология концептов / под ред. В.И. Карасика, И.А. Стернина. Москва : Гнозис, 2007. C. 182-197.

7. Засекін С.В. Психолінгвістичні універсалії перекладу художнього тексту : монографія. Луцьк : Волин. нац. ун-т ім. Лесі Українки, 2012. 276 с.

8. Колодинская Е.В. Историческое прошлое как предмет высказввания: современная англоязычная постмодернистская историография (Г. Свифт, Дж. Барнс). Авторедр дисс. канд. фрилол. наук. 10.01.03. - «литература народов стран зарубежья (европейская и американская литературы). Москва, 2004. 24 с.

9. Кузьмина Н.А. Интертекст и его роль в процессах эволюции поэтического языка. Изд. 3-е испр и доп. Москва : КомКнига, 2006. 272 с.

10. Кухаренко В.А. Інтерпретація тексту : навч. посіб. Вінниця : НОВА КНИГА, 2004. 272 с. 
11. Новикова М.О. Міфи та місія. Київ : ДУХ І ЛІТЕРА, 2005. 432 с.

12. Норман Б.Ю. Когнитивный синтаксис русского языка : учеб. пособие. Москва : ФЛИНТА, 2013. 254 с.

13. Сапрыгина Н.В. Психолингвистика художественного текста: коммуникация автора и читателя : [монография]. Одесса : Астропринт, 2012. 336 с.

14. Сдобников В.В. Теория перевода : учеб пособ. Москва : АСТ Восток - Запад, 2007. 448 с. («Лингвистика и межкультурная коммуникация»).

15. Селіванова О.О. Опозиція СВІЙ / ЧУЖИЙ в етнос відомості (на матеріалі українських паремій) // Світ свідомості в мові. Мир сознания в языке. Монографічне видання. Черкаси : Ю. Чабаненко, 2012. С. $196-211$.

16. Селіванова О.О. Сучасна лінгвістика: напрями та проблеми: підручн. Полтава : Довкілля-К, 2008.712 с.

17. Степанов Ю.С. Константы: Словарь русской культуры [Изд. 3-е.]. Москва : Академический проект, 2004.992 с.

18. Стилистика английского языка: Учебник / А.Д. Мороховский, О.П. Воробьева, Н.И. Лихошерст, З.В. Тимошенко. Київ : Вища школа, 1991. 272 с.

19. Сухорольська С.М., Федоренко О.І. Методи лінгвістичних досліджень. Львів : Видавничий центр ЛНУ імені Івана Франка, 2006. 344 с.

20. Сучасна українська літературна мова. Стилістика / за заг. ред. І.К. Білодіда. Київ : Наукова думка, 1972.587 с.

21. Baker M. In other words: A textbook of translation. L. \& N.Y.: Routledge, 2006. 304 p.

22. Leech G., Short M. Style in Fiction A Linguistic Introduction to English Fictional Prose. Second edition. London \& New York: Longman, Pearson, 2007. 404 p.

23. Болотнова Н.С. Коммуникативная стилистика текста : словарь-тезаурус. Москва : Флинта: Наука, 2009.384 с.

24. Жайворонок В.В. Знаки української етнокультури : словник-довідник. Київ : Довіра, 2007. 703 с.

25. Літературознавчий словник-довідник / за ред. Р.Т. Гром'яка, Ю.І. Коваліва, В.І. Теремка. Київ : ВЦ «Академія», 2007. 752 с. (Nota bene)

26. Мартинюк А.П. Словник термінів когнітивно-дискурсивної лінгвістики. Харків : ХНУ імені В.Н. Карабіна, 2011. 196 c.

27. Словник української мови:В 11-ти т. / Редкол.: І.К. Білодід (голова) та інші. Київ : Наук. думка, 1970-1980. Т. 1-11.

28. Longman Exams Dictionary. Edinburg: Pearson Education Ltd, 2006. 1834 p.

29. Барнс Д. Історія світу в $10 \frac{1}{2}$ розділах; перекл з англ. Г. Яновської. Харків : Книжковий Клуб «Клуб сімейного дозвілля», 2019. 352 с

30. Barnes J. A History of the World in $10 \frac{1}{2}$ Chapters. London : Vintage, 2009. 309 p. 